\title{
Wettelijke streefcijfers over man-vrouw- diversiteit vanuit het perspectief van de selectie- en benoemingscommissies van grote vennootschappen
}

\author{
B. Klinger, H.M. Vletter-van Dort \& H. Koster
}

\section{Inleiding}

Per 1 januari 2013 heeft de vertegenwoordiging van vrouwen in de raad van bestuur $(\mathrm{RvB})$ en raad van commissarissen $(\mathrm{Rv} C)$ van grote Nederlandse naamloze en besloten vennootschappen een plek gekregen in de Nederlandse wetgeving. Om kapitaalvennootschappen te bewegen meer vrouwen in hun $\mathrm{RvB}$ en $\mathrm{RvC}$ te benoemen, zijn art. 2:166 en 2:276 Burgerlijk Wetboek (BW) geïntroduceerd. Deze bepalingen schrijven voor dat ten minste $30 \%$ van de $\mathrm{RvB}$ en de $\mathrm{Rv} C$ van een grote naamloze vennootschap (nv) en een grote besloten vennootschap (bv) moet bestaan uit vrouwen, respectievelijk mannen. Dit percentage is evenwel niet afdwingbaar en wordt daarom een streefcijfer genoemd. ${ }^{1}$

Zolang de op grond van art. 2:166 respectievelijk art. 2:276 BW te bereiken streefcijfers niet zijn gehaald, moeten grote nv's en bv's op basis van art. 2:391 lid 7 BW in hun bestuursverslag uiteenzetten waarom er geen evenwichtige verdeling is, welke stappen de vennootschap heeft gezet om in de toekomst tot een evenwichtige verdeling te komen, en welke stappen de vennootschap gaat nemen om een evenwichtige verdeling te bereiken ('pas toe of leg uit'). De accountant die belast is met de controle van de jaarrekening en het bestuursverslag moet controleren of deze uitleg aanwezig is. Wordt de uitleg niet gegeven, dan moet dit gemeld worden in de accountantsverklaring. Het is vervolgens aan de algemene vergadering van aandeelhouders om te beoordelen of de gegeven uitleg adequaat is. ${ }^{2}$ Kroeze betreurde bij de invoering van het wettelijk streefcijfer al de keuze voor dit 'pas toe of leg uit'-beginsel en noemde het zelfs niet krachtiger dan zelfregulering. ${ }^{3} \mathrm{Dit}$ standpunt heeft anno 2019 nog niet aan relevantie verloren. Uit onderzoek van de Commissie Monitoring Talent naar de Top (hierna: Commissie Monitoring) blijkt dat maar zeer weinig bedrijven in hun jaarverslag uitleggen waarom zij niet

1 Dat blijkt uit de bewoordingen 'wordt (...) zoveel mogelijk rekening gehouden met' in het tweede lid van art. 2:166 en 2:276 BW.

2 Ontbreekt de uitleg, dan voldoet het bestuursverslag niet aan de wettelijke voorschriften en kan iedere belanghebbende op grond van art. 2:447 jo. art. 2:448 BW aan de Ondernemingskamer verzoeken om te bevelen dat het bestuursverslag wordt ingericht overeenkomstig de door haar te geven aanwijzingen. Bij beursvennootschappen is de AFM ook bevoegd tot het indienen van een dergelijk verzoek.

3 M.J. Kroeze, Enough room for mediocre men and women, Ondernemingsrecht 2013/49. 
aan het streefcijfer voldoen. ${ }^{4}$ Uit recente onderzoeken over de jaren 2016, 2017 en 2018 blijkt voorts dat het aantal vrouwen dat is benoemd in de $\mathrm{RvB}$ of $\mathrm{RvC}$ aan het toenemen is, maar ook dat de toename traag verloopt. ${ }^{5}$ In de Emancipatiemonitor 2018 wordt ter zake opgemerkt dat het in dit tempo nog twintig jaar zal gaan duren voordat sprake is van een gelijke man-vrouwverhouding in de top. ${ }^{6}$ De huidige minister van Onderwijs, Cultuur en Wetenschap (OCW) noemt de vorderingen zelfs 'om te huilen'.

In dit artikel onderzoeken wij de streefcijfers over man-vrouwdiversiteit specifiek vanuit het perspectief van de selectie- en benoemingscommissie. ${ }^{8}$ Deze commissie, indien ingesteld, ${ }^{9}$ vervult in de praktijk bij beursvennootschappen een belangrijke rol bij de benoeming van bestuurders en commissarissen. In paragraaf 2 bespreken wij daartoe eerst de achtergrond van de wettelijke regeling inzake streefcijfers. Daarna doen wij in paragraaf 3 verslag van de uitkomsten van onderzoek naar de huidige samenstelling van de $\mathrm{RvB}$, de RvC en de selectie- en benoemingscommissies van beursgenoteerde Nederlandse ondernemingen. Vervolgens gaan wij in paragraaf 4 in op de sociologische factoren die de ondervertegenwoordiging van vrouwen in de vennootschapstop kunnen verklaren. Wij sluiten in paragraaf 5 af met enkele conclusies.

\section{De wettelijke regeling inzake streefcijfers over man-vrouwdiversiteit}

De wettelijke regeling inzake streefcijfers is op 1 januari 2013 geïntroduceerd in het Nederlandse vennootschapsrecht door de Wet bestuur en toezicht. ${ }^{10}$ De regeling is opgenomen naar aanleiding van het amendement van de (toenmalige) Tweede Kamerleden Kalma, Van Vroonhoven-Kok en Weekers van 1 december $2009 .{ }^{11}$ Dat het aantal vrouwen aan de top op natuurlijke wijze - dus zonder tussenkomst van regelgeving - zou groeien, werd onwaarschijnlijk geacht door de

4 Dit is een organisatie die jaarlijks vennootschappen monitort op overeenstemming met het wettelijk streefcijfer, zie Bedrijvenmonitor Topvrouwen 2017, p. 16.

5 Zie de resultaten van de Bedrijvenmonitor Topvrouwen 2017, p. 26, de Dutch Female Board Index 2018, p. 4, en de Emancipatiemonitor 2018, p. 46-47. Zie voorts ook C.F. Perquin-Deelen, Diversiteit op de werkvloer: de recente cijfers, Ondernemingsrecht 2018/108.

$6 \quad$ Emancipatiemonitor 2018, p. 47.

7 L. van der Leij, Minister: aandeel vrouwelijke bestuurders 'om te huilen', FD 6 maart 2018. De ministers van OCW en SZW hebben op 29 juni 2018 de SER advies gevraagd over diversiteit in de top van het Nederlandse bedrijfsleven.

8 Zie voor een recente evaluatie van de deze wettelijke regeling het WODC-rapport Evaluatie Wet bestuur en toezicht. Wetenschappelijk evaluatieonderzoek naar de werking van de nieuwe bepalingen uit de Wet aanpassing regels bestuur en toezicht nv/bv (IVO-serie nr. 110), Deventer: Wolters Kluwer 2018 (hierna: WODC-rapport 2018).

9 Op basis van best principe bepaling 2.3.2 van de Nederlandse Corporate Governance Code stelt de $\mathrm{RvC}$, indien hij uit meer dan vier leden bestaat, uit zijn midden onder meer een selectie- en benoemingscommissie in.

10 Stb. 2012, 455.

11 Kamerstukken II 2009/10, 31763, 14. 
indieners. ${ }^{12}$ De toelichting op het amendement onderstreepte dat uit internationaal onderzoek blijkt dat een eenzijdige vennootschapstop leidt tot slechtere financiële resultaten en vanuit arbeidsmarktbeleid problematisch is. ${ }^{13}$ Verschillende onderzoeken ondersteunen de stelling dat vrouwelijke kenmerken een positieve invloed kunnen hebben op (effectief) leiderschap, en in het verlengde daarvan op de bedrijfsresultaten. ${ }^{14}$

De wettelijke regeling inzake streefcijfers geldt alleen voor grote nv's en bv's. ${ }^{15}$ Grote vennootschappen zijn vennootschappen die aan ten minste twee van de volgende drie vereisten voldoen: (1) de waarde van de activa volgens de balans met toelichting bedraagt, op de grondslag van de verkrijgings- en vervaardigingsprijs, ten minste $€ 20$ miljoen; (2) de netto-omzet over het boekjaar bedraagt ten minste $€ 40$ miljoen; en (3) het gemiddeld aantal werknemers over het boekjaar bedraagt ten minste $250 .{ }^{16}$ De wettelijke regeling inzake streefcijfers heeft betrekking op de zetels in de RvB en de RvC. Het streefcijfer van $30 \%$ geldt ook voor een monistisch bestuur, ${ }^{17}$ maar niet duidelijk is of het streefcijfer geldt voor het monistische bestuur als geheel of per groep van uitvoerende en niet-uitvoerende bestuurders. ${ }^{18}$ Lidmaatschap van het executive committee of het managementteam valt buiten de reikwijdte van de wettelijke regeling inzake streefcijfers, maar valt wel binnen het bereik van de Corporate Governance Code (zie hierna).

Van een evenwichtige verdeling in de zin van art. 2:166/276 lid 1 BW is sprake indien ten minste $30 \%$ van de zetels wordt bezet door vrouwen en ten minste $30 \%$ door mannen, voor zover de zetels worden bezet door natuurlijke personen. Rechtspersoon-bestuurders tellen niet mee voor de berekening van de percentages. ${ }^{19}$ Op grote nv's en bv's rust in dat kader op grond van art. 2:166/276 lid 2 BW de verplichting om ten behoeve van een evenwichtige verdeling van de zetels

12 Kamerstukken II 2009/10, 31763, 14, p. 3. Waarop zij die verwachting baseerden, werd overigens niet toegelicht.

13 Kamerstukken II 2009/10, 31763, 14, p. 3. Verwijzingen naar literatuur ontbreken evenwel.

14 Zie o.a. A.H. Eaglya \& L.L. Carli, The female leadership advantage: An evaluation of the evidence, The Leadership Quarterly (14) 2003, afl. 6, p. 807-834; S. Nielsen \& M. Huse, The contribution of women on boards of directors: Going beyond the surface, Corporate Governance: An International Review (18) 2010, afl. 2, p. 136-148.

15 Daarnaast geldt de regeling ook voor de Societas Europaea (SE). Voor de SE geldt dat deze in iedere lidstaat wordt behandeld als een nv die is opgericht volgens het recht van de lidstaat waar de SE haar statutaire zetel heeft. Zie art. 10 Verordening (EG) 2157/2001 van de Raad van 8 oktober 2001 betreffende het statuut van de Europese vennootschap (SE), PbEG 2001, L 294/1.

16 Zie art. 2:397 lid 1 BW.

17 Kamerstukken II 2009/10, 31763, 14, p. 3.

18 P.J. Dortmond, M.J. Kroeze \& R.G.J. Nowak, De aangenomen amendementen bij de wetsvoorstellen bestuur en toezicht flexibilisering bv-recht, spreekrecht OR, uitvoeringswet aandeelhoudersrichtlijn en invoeringswet titel 7.13 BW, Ondernemingsrecht 2010/9.

19 De streefcijferregeling kent een bepaling voor het geval een of meer bestuurszetels worden bezet door een nv of bv. In dat geval moet op grond van art. 2:166 lid 3 BW voor de nv of art. 2:276 lid 3 BW voor de bv het streefcijfer worden toegepast op het bestuur van de als bestuurder optredende nv of bv. 
van het bestuur en de RvC 'zo veel mogelijk rekening te houden' met een evenwichtige verdeling over mannen en vrouwen bij:

- het benoemen en voordragen van (uitvoerende en niet-uitvoerende) bestuurders;

- het opstellen van een profielschets voor de omvang en de samenstelling van de $\mathrm{RvC}$;

- het aanwijzen, benoemen, aanbevelen en voordragen voor benoeming tot commissaris;

- het opstellen van een profielschets voor de niet-uitvoerende bestuurders;

- het voordragen, benoemen en aanbevelen voor benoeming van niet-uitvoerende bestuurders. ${ }^{20}$

Wij maken een uitstapje naar de Nederlandse Corporate Governance Code 2016 (hierna: Code 2016). In de Code 2016 zijn twee specifieke bepalingen met betrekking tot het diversiteitsbeleid van de beursvennootschap opgenomen. Best practice bepaling 2.1.5 van de Code 2016 luidt als volgt:

'De raad van commissarissen stelt een diversiteitsbeleid op voor de samenstelling van het bestuur, de raad van commissarissen en, indien aanwezig, het executive committee. In het beleid wordt ingegaan op de concrete doelstellingen ten aanzien van de diversiteit en de voor de vennootschap relevante aspecten van diversiteit, zoals nationaliteit, leeftijd, geslacht en achtergrond inzake opleiding en beroepservaring. ${ }^{21}$

Voorts bepaalt best practice bepaling 2.1.6:

'In de corporate governance verklaring worden het diversiteitsbeleid en de uitvoering daarvan toegelicht. Hierbij wordt ingegaan op: i. de doelstellingen van het beleid; ii. de wijze waarop het beleid is uitgevoerd; en iii. de resultaten van het beleid in het afgelopen boekjaar. Indien de samenstelling van het bestuur en de raad van commissarissen afwijkt van de doelstellingen van het diversiteitsbeleid van de vennootschap en/of van het streefcijfer voor de verhouding man-vrouw, indien en voorzover dit bij of krachtens de wet is bepaald, wordt in de corporate governance verklaring tevens toegelicht wat de stand van zaken is, welke maatregelen worden genomen om de nagestreefde situatie wel te bereiken en op welke termijn.'

Vennootschappen dienen derhalve niet alleen te verantwoorden welke maatregelen zijn genomen, maar moeten ook, evenals grote vennootschappen op basis van art. 2:391 lid 7 BW, laten zien welke maatregelen zullen worden genomen. De Code 2016 bevat evenwel geen diversiteitstreefcijfer. Wel ziet de Code 2016

20 Zie hierover WODC-rapport 2018, p. 421.

21 Met het diversiteitsbeleid moet rekening worden gehouden bij het opstellen van de profielschets voor de $\mathrm{RvC}$, die op de website van de vennootschap moet worden geplaatst. Zie best practice bepaling 2.1.1. 
anders dan de wettelijke regeling inzake de streefcijfers ook op het executive committee.

De wettelijke regeling inzake streefcijfers is per 1 januari 2016 van rechtswege komen te vervallen. ${ }^{22}$ In de toelichting op het amendement ontbreekt iedere verklaring waarom de indieners destijds gekozen hebben voor een tijdelijke werking van de wettelijke regeling inzake streefcijfers. De minister geeft in de memorie van antwoord evenmin een verklaring hiervoor. ${ }^{23}$ Hij geeft slechts aan dat het aan het kabinet is om de situatie in 2016 te evalueren en te beslissen over een eventuele verlenging van de bepalingen inzake het wettelijk streefcijfer. ${ }^{24}$ Het wettelijk streefcijfer bleek in 2016 bij lange na niet te zijn gehaald. In haar brief aan de Tweede Kamer eind 2015 stelde de toenmalige minister van OCW al aan de orde dat na bijna vier jaar de wet nog onvoldoende had gewerkt, ondanks verschillende inspanningen. ${ }^{25}$ Daarop werd besloten tot een verlenging van de wettelijke regeling. Dit heeft ertoe geleid dat het wettelijk streefcijfer na een onderbreking van ruim vijftien maanden opnieuw in dezelfde vorm in werking is getreden per 13 april 2017. ${ }^{26}$ Ingevolge deze verlenging heeft het bedrijfsleven tot 1 januari 2020 de kans om een daadwerkelijk evenwichtig samengestelde vennootschapstop te realiseren. ${ }^{27}$ Uit de memorie van toelichting (hierna: MvT) bij het wetsvoorstel ter zake de verlenging blijkt dat er sinds de invoering in 2013 sprake is van een lichte groei in de man-vrouwverhouding ten opzichte van de situatie in 2012. ${ }^{28}$ Ondanks dat er dus enige vooruitgang is geboekt, doen deze cijfers geen recht aan het potentieel aan vrouwelijk talent, zo valt te lezen in de MvT. ${ }^{29}$ Daarom is ervoor gekozen om het wettelijk streefcijfer met vier jaar te verlengen. ${ }^{30}$

Kamerstukken II 2015/16, 34435, 2.

23 Kamerstukken I 2010/11, 31763, C.

24 Kamerstukken I 2010/11, 31763, C, p. 25.

25 Kamerstukken II 2015/16, 32637, 227, p. 3.

26 Wijziging van boek 2 van het Burgerlijk Wetboek in verband met het voortzetten van het streefcijfer voor een evenwichtige verdeling van de zetels van het bestuur en de raad van commissarissen van grote naamloze en besloten vennootschappen (34 435), Stb. 2017, 68.

27 Kamerstukken II 2015/16, 30420, 227.

28 Kamerstukken II 2015/16, 34435, 2.

29 Kamerstukken II 2015/16, 34435, 2, p. 2.

30 Op grond van EU-richtlijn 2014/95/EU betreffende de bekendmaking van niet-financiële informatie en informatie inzake diversiteit door bepaalde grote ondernemingen en groepen (PbEU 2014, L 330) moeten grote beursvennootschappen in het bestuursverslag ook een beschrijving geven van het diversiteitsbeleid dat zij voeren met betrekking tot het bestuur en de RvC, de doelstellingen van dit beleid, de wijze van tenuitvoerlegging en de resultaten in de verslagperiode. Het diversiteitsbeleid kan betrekking hebben op leeftijd, geslacht en achtergrond inzake opleiding en beroepservaring. De bepalingen over het wettelijk streefcijfer voor grote nv's en bv's kunnen worden gezien als een nadere invulling van de bepalingen over het diversiteitsbeleid voor grote beursvennootschappen, in zoverre dit betrekking heeft op geslacht. Voor wat betreft de informatie inzake diversiteit heeft Nederland deze richtlijn geïmplementeerd door het Besluit bekendmaking diversiteitsbeleid, Stb. 2016, 559. 


\section{De huidige samenstelling van de $\mathrm{RvB}$, de $\mathrm{RvC}$ en van selectie- en benoemingscommissies}

\subsection{Samenstelling van de $R v B$ en $R v C$}

'Een beetje beter, maar nog lang niet voldoende', zo luidt de titel van de Bedrijvenmonitor Topvrouwen 2017 (hierna: de Bedrijvenmonitor 2017) van 1 december 2017. ${ }^{31}$ De Monitoring Commissie, verantwoordelijk voor het onderzoek, onderzoekt jaarlijks hoever de vennootschappen zijn met de realisatie van het streefcijfer, de inspanningen die bedrijven daarvoor leveren, hun ambities voor de toekomst en hoe zij in hun jaarverslag rapporteren over de man-vrouwverdeling. Op basis van de resultaten doet de Monitoring Commissie aanbevelingen aan de minister van OCW. ${ }^{32}$ Uit de Bedrijvenmonitor 2017 blijkt dat de groei gering is. In de RvB steeg het aantal vrouwen ten opzichte van 2012 van 7,4\% naar 10,7\% eind 2016 en medio 2017 tot $11,7 \%$. Bij de RvC was een stijging te zien van 9,8\% in 2012 naar 15,0\% in 2016 en tot 16,2\% in 2017. ${ }^{33}$ Medio 2017 hadden $70 \%$ van de RvB's en 49,5\% van de RvC's geen enkele vrouw. Uit het rapport blijkt dat slechts bij $19,1 \%$ van de RvB's en bij $24,8 \%$ van de RvC's het wettelijk streefcijfer gerealiseerd is in $2017 .{ }^{34}$ In 2012 lag dit percentage voor de RvB's op 9,3\% en voor de RvC's op 14,7\%. Het aantal bedrijven dat een evenwichtige verhouding in zowel de RvB als de RvC heeft, is sinds 2012 (4,5\%) licht gegroeid. In 2016 lag dat percentage op 5,8\% en in 2017 op 6,4\%. ${ }^{35}$ De groei van het aantal vrouwen in de $\mathrm{RvB}$ en $\mathrm{RvC}$ hangt samen met vacatures in de periode 2016-2017. In 20\% van de RvB's en 28\% van de RvC's vonden in 2016 nieuwe benoemingen plaats. Slechts bij $26 \%$ van de RvB's en bij 37,1\% van de RvC's werd een vrouw benoemd. Ook blijkt dat de transparantie in het jaarverslag over de man-vrouwverdeling nog onvoldoende is. Weliswaar is het aantal bedrijven dat niets rapporteert afgenomen van 54\% in 2012 naar 35\% in 2017, maar desondanks is het teleurstellend dat meer dan de helft van de bedrijven geen enkele uitleg geeft over de onevenwichtige verdeling in de vennootschapstop. ${ }^{36}$ Minder dan $10 \%$ van de $\mathrm{RvC}$ en $\mathrm{RvB}$ voldoet aan de wettelijke rapportageverplichtingen voor boekjaar 2016. ${ }^{37}$ Een andere uitkomst van het onderzoek is dat bedrijven in 2016 ten opzichte van 2015 weinig maatregelen hebben genomen om de zetels evenwichtiger te verdelen. Uit het onderzoek blijkt dat (in 2017) $46 \%$ van de vennootschappen geen beleid heeft voor de RvB en dat $38 \%$ dat niet heeft voor de samenstelling van de $\mathrm{RvC} .^{38}$

31 Ten tijde van de afronding van dit artikel (begin 2019) was de Bedrijvenmonitor Topvrouwen 2018 nog niet verschenen.

32 Bedrijvenmonitor Topvrouwen 2017, p. 3.

33 Bedrijvenmonitor Topvrouwen 2017, p. 26.

34 Bedrijvenmonitor Topvrouwen 2017, p. 31-32.

35 Bedrijvenmonitor Topvrouwen 2017, p. 31-32.

36 Bedrijvenmonitor Topvrouwen 2017, p. 42.

37 Bedrijvenmonitor Topvrouwen 2017, p. 43.

38 Bedrijvenmonitor Topvrouwen 2017, p. 83. 
Uit de Emancipatiemonitor 2018 blijkt dat van 2015 tot en met 2017 het aandeel vrouwen in de $\mathrm{RvB}$ en $\mathrm{RvC}$ van de grootste 5000 bedrijven is toegenomen. Alleen in de groep van grootste 25 bedrijven nam het aandeel vrouwen in de $\mathrm{RvC}$ af. ${ }^{39}$ Over het algemeen is de stijgende lijn die in de jaren vóór 2015 gaande was voor de $\mathrm{RvB}$ en $\mathrm{RvC}$ voortgezet. Niettemin is maar een op de vijf bestuurders van de grootste 500 bedrijven en krap een op de zes bestuurders van de grootste 5000 bedrijven een vrouw. ${ }^{40}$ Ten slotte volgt uit de Nederlandse Female Board Index $2018^{41}$ dat de percentages vrouwelijke bestuurders en commissarissen per 31 augustus 2017 en 31 augustus 2018 beide exact gelijk zijn gebleven, respectievelijk $6 \%$ en $25 \% .{ }^{42}$ Ook blijkt uit de Nederlandse Female Board Index 2018 dat bij de 77 ondernemingen zonder vrouwelijke bestuurder tussen 31 augustus 2017 en 31 augustus 201830 nieuwe mannelijke bestuurders zijn benoemd. ${ }^{43}$

\subsection{De samenstelling van selectie- en benoemingscommissies}

Indien de $\mathrm{RvC}$ uit meer dan vier leden bestaat, dient de $\mathrm{RvC}$ op grond van de Nederlandse Corporate Governance Code uit zijn midden een selectie- en benoemingscommissie in te stellen. ${ }^{44}$ Een belangrijke taak van deze commissie is dat zij de selectiecriteria en benoemingsprocedures voor bestuurders en commissarissen opstelt. Daarnaast beoordeelt zij tussentijds het functioneren van de bestuurders en commissarissen, stelt een plan op voor opvolging van bestuurders en commissarissen en doet voorstellen voor (her)benoemingen. ${ }^{45}$ Doordat zij belast zijn met deze taken hebben de leden van de selectie- en benoemingscommissie grote invloed op de te benoemen functionarissen, en daarmee op de samenstelling van de $\mathrm{RvB}$ en RvC. Eerstgenoemde auteur van dit artikel heeft onderzoek verricht naar de samenstelling van de selectie- en benoemingscommissies van Nederlandse beursvennootschappen ${ }^{46}$ per 30 april 2018. Figuur 1 geeft de uitkomsten van de man-vrouwverhouding binnen de selectie- en benoemingscommissies.

In totaal hebben 193 commissarissen zitting in een selectie- en benoemingscommissie. $49(25,4 \%)$ van hen zijn vrouwen en $144(74,6 \%)$ van hen zijn mannen. ${ }^{47}$ Uit het onderzoek blijkt voorts:

1 In totaal is bij 62 van de 91 onderzochte ondernemingen een selectie- en benoemingscommissie ingesteld (68,1\%).

39 Zie Emancipatiemonitor 2018, p. 46.

40 Zie Emancipatiemonitor 2018, p. 46-47.

41 De Nederlandse Female Board Index 2018 betreft een overzicht van de vrouwelijke vertegenwoordiging in de RvB en RvC van 90 Nederlandse nv's die genoteerd zijn op Euronext Amsterdam.

42 Zie de Dutch Female Board Index 2018, p. 4.

43 Zie de Dutch Female Board Index 2018, p. 4.

44 Best practice bepaling 2.3.

45 Best practice bepaling 2.2.5.

46 Dit onderzoek is door de eerstgenoemde auteur verricht in het kader van haar scriptieonderzoek.

47 Bij sommige vennootschappen was geen benoemingscommissie ingesteld, zwijgt het jaarverslag daarover of was onduidelijk wie daarvan deel uitmaakt. 


\section{Figuur 1 De totale verhouding aantal vrouwen en mannen in de onderzochte} beursvennootschappen op 30 april 2018

Totale $\mathrm{m} / \mathrm{v}$-verhouding benoemingscommissies

beursgenoteerde Nederlandse ondernemingen

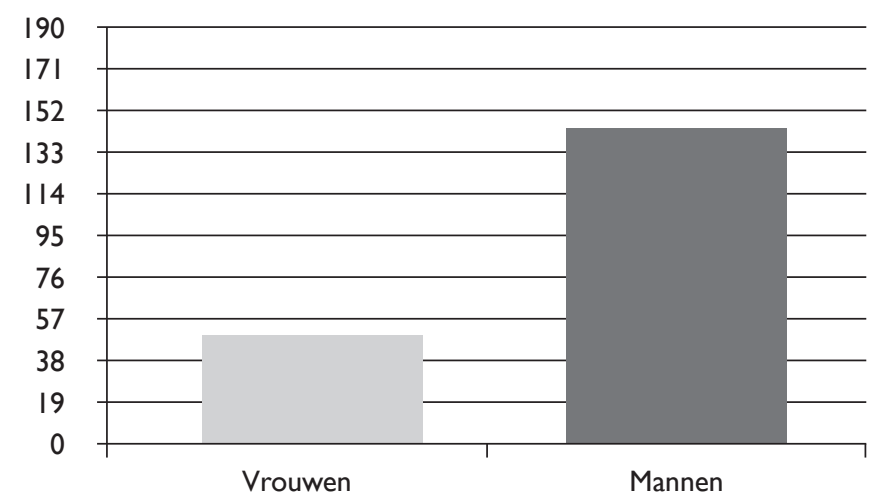

Vrouwen

Mannen

2 In 36 van deze 62 commissies hebben vrouwen zitting $(58,1 \%)$.

3 In 6 van deze 62 commissies hebben meer vrouwen dan mannen zitting $(9,7 \%)$.

424 selectie- en benoemingscommissies hebben 0 vrouwen, daarmee zijn er dus 24 commissies waarin uitsluitend mannen zitting hebben (38,7\%). ${ }^{48}$

5 Er zijn 0 selectie- en benoemingscommissies waarin 0 mannen zitting hebben (0\%).

6 Er zijn 0 selectie- en benoemingscommissies waarin uitsluitend vrouwen zitting hebben (0\%).

7 Er zijn 30 selectie- en benoemingscommissies die bestaan uit drie leden $(48,4 \%) .26$ daarvan bestaan overwegend uit mannen (twee derde of meer) (86,7\%). 10 van de 30 commissies bestaan uitsluitend uit mannen (33,33\%). In slechts 4 commissies met drie leden zijn er meer vrouwen dan mannen (13,3\%).

8 In 7 van de 62 selectie- en benoemingscommissies is er een gelijke verdeling tussen mannen en vrouwen $(11,3 \%)$.

Uit deze onderzoeksresultaten valt op te maken dat de selectie- en benoemingscommissies overwegend uit mannen bestaan. Er zijn weinig selectie- en benoemingscommissies waar vrouwen de meerderheid vormen. Sterker nog, er zijn meer commissies - te weten vier keer zoveel - zonder vrouwen dan commissies waarin meer vrouwen dan mannen zitting hebben.

48 Bij twee vennootschappen was het niet duidelijk wie deel uitmaakt van de commissie. Het feit dat er een commissie was, is dan meegenomen, maar de samenstelling daarvan niet vanwege het ontbreken van de relevante data. 
In de volgende paragraaf zal aan bod komen of de bezetting van de selectie- en benoemingscommissies gevolgen heeft voor de keuze van kandidaten en daarmee voor de samenstelling van de $\mathrm{RvB}$ en $\mathrm{RvC}$.

\section{Sociologische factoren}

\subsection{Genderstereotypering}

Een eerste relevante factor die wij bespreken, is genderstereotypering. ${ }^{49}$ Gender wordt wel omschreven als het geheel van sociale en culturele kenmerken van een sekse. ${ }^{50}$ Gender is niet iets wat een mens heeft of is en staat dus niet vast, in tegenstelling tot geslachtskenmerken die wel onveranderlijk zijn. ${ }^{51}$ Uit verschillende onderzoeken blijkt verder dat er meer verschillen zijn tussen individuele mannen en vrouwen onderling dan tussen de vrouw en de man als groep. ${ }^{52}$ Mannen en vrouwen zijn dus niet twee afzonderlijke homogene groepen. ${ }^{53}$ De maatschappij leert ieder mens van jongs af aan hoe zij of hij zich zou moet gedragen in overeenstemming met haar of zijn geslachtskenmerken. ${ }^{54}$ Het sociaal wenselijke gedrag dat een meisje en een jongen moeten tonen om respectievelijk als meisje of jongen aangemerkt te worden, wordt aangeleerd via de opvoeding, ${ }^{55}$ maar ook via het onderwijssysteem, ${ }^{56}$ de media, ${ }^{57}$ het geloof, ${ }^{58}$ en door middel van taal. ${ }^{59}$ Gender structureert vervolgens het sociale leven door (gender)stereotypes in het leven te roepen, die door dagelijkse interacties in stand worden gehouden. ${ }^{60}$ Stereotypes reflecteren over het algemeen de algemene verwachtingen van leden van een bepaalde sociale groep. ${ }^{61} \mathrm{Zij}$ vertegenwoordigen opvattingen over psychosociale kenmerken van een vrouw of een man. Vrouwen en mannen kunnen zich

49 N. Ellemers, Gender stereotypes, The Annual Review of Psychology 2018, p. 277-278.

50 Van Dale Groot Woordenboek van de Nederlandse Taal (14de druk), Utrecht: Van Dale Lexicografie 2005.

51 J. Lorber, Night to his day: The social construction of gender, New Haven: Yale University Press 1994, p. 55-59.

52 Lorber 1994, p. 55-59; C. West \& D.H. Zimmerman, Doing gender, Gender \& Society (1) 1987, p. 125.

53 L. Wirth, Women in management: Closer to breaking through the glass ceiling?, in: M.F. Loutfi (red.), Women, gender and work: What is equality and how do we get there?, Genève: International Labor Office 2001, p. 245.

54 L. Franklin, Gender, Hampshire: Palgrave Macmillan 2012, p. 36-37 en 44.

55 R.W. Connell, Gender, Cambridge: Polity Press 2002, p. 4; Ellemers 2018, p. 279-280.

56 Connell 2002, p. 4; Franklin 2012, p. 46-48.

57 Connell 2002, p. 4; Franklin 2012, p. 54-55.

58 Connell 2002, p. 4.

59 M-T. Claes, Women, men and management styles, in: M.F. Loutfi (red.), Women, gender and work: What is equality and how do we get there?, Genève: International Labor Office 2001, p. 387.

60 Connell 2002, p. 10; L. Westbrook \& K. Schilt, Doing gender, determining gender: Transgender people, gender panics, and the maintenance of the sex/gender/sexuality system, Gender \& Society 2014, p. 36.

61 Ellemers 2018, p. 276; L.A. Rudman \& J.E. Phelan, Sex differences, sexism and sex: The social psychology of gender from past to present, Social Psychology of Gender 2015, p. 24 en 127-128; Westbrook \& Schilt 2014, p. 35. 
overeenkomstig die verwachtingen leren te gedragen, waardoor deze gedragingen natuurlijk aanvoelen. ${ }^{62}$ Een gevolg van genderstereotypering is dat de gedragingen van vrouwen en mannen nogal eens beoordeeld worden in overeenstemming met wat van ieder van hen verwacht wordt. ${ }^{63}$ Ook al zouden een vrouw en een man exact hetzelfde gedrag vertonen, dan kunnen hun gedragingen alsnog anders beoordeeld worden om de eenvoudige reden dat hun gedrag gewaardeerd wordt op grond van hun gender. ${ }^{64}$ De aan die persoon toegeschreven genderrol kan dus het beoordelingsvermogen van een persoon beïnvloeden. ${ }^{65}$

Genderstereotypes geven ook aan wat de eigenschappen zijn waarover elke vrouw en man zou moeten beschikken. ${ }^{66}$ Veronderstelde kenmerken van een stereotype vrouw zijn onder andere dat zij zorgzaam, zachtaardig, empathisch, geïnteresseerd, warm en bescheiden moet zijn en dat zij in de regel een groot verantwoordelijkheidsgevoel moet hebben. ${ }^{67}$ Van vrouwen wordt verwacht dat zij eerder de groep vooropstellen dan zichzelf. Daarnaast behoort bij de vrouw de familie hoog in het vaandel te staan. ${ }^{68}$ Van een man daarentegen wordt doorgaans verwacht dat hij harder is, competitiever en meer gericht op prestige. Mannen gaan eerder voor individueel gewin dan voor het collectief en zijn prestatiegerichter dan vrouwen, zo is de gedachte. ${ }^{69}$ De man ziet zijn werk als voornaamste prioriteit. ${ }^{70}$ Deze kenmerken, althans veronderstellingen, werken door in verschillende domeinen van het leven en scheppen daarmee in die verschillende domeinen verwachtingen, zoals in het gezinsleven en beroepsgroepen. Genderstereotypering van vrouwen en mannen is problematisch, omdat mensen zich niet bewust zijn van het feit dat zij de gecreëerde verschillen in stand houden en dat deze hun beoordelingsvermogen beïnvloeden. ${ }^{71}$

Genderstereotypering beïnvloedt de wijze waarop de mens kwaliteiten en vaardigheden van een vrouw en een man beoordeelt in alle facetten van het leven. ${ }^{72}$ Het kan de potentie van een vrouw of een man bepalen wanneer zij geselecteerd worden voor een baan, en of zij geschikt worden geacht voor die baan. Daarmee kan genderstereotypering eveneens gevolgen voor de carrièreperspectieven van vrouwen hebben. ${ }^{73}$ Belangrijk om hierbij in het achterhoofd te houden is dat mannen der in Management: An International Journal (27) 2012, afl. 2, p. 120.

63 A.C. Rosen, Gender stereotypes, ascribed gender and social perception, Perceptual and Motor Skills (45) 1977, p. 851.

64 M.E. Heilman \& E.J. Parks-Stamm, Gender stereotypes in the workplace: Obstacles to women's career progress, Social Psychology of Gender (24) 2007, p. 52.

65 Rosen 1977, p. 859.

66 Connell 2002, p. 76-77; Heilman \& Parks-Stamm 2007, p. 58.

67 Heilman \& Parks-Stamm 2007, p. 48 en 58-59.

68 Heilman \& Parks-Stamm 2007, p. 48 en 58-59.

69 Heilman \& Parks-Stamm 2007, p. 48 en 58-59; West \& Zimmerman 1987, p. 137-138.

70 Ellemers 2018, p. 280.

71 Heilman \& Parks-Stamm 2007, p. 49.

72 Ellemers 2018, p. 279.

73 Ellemers 2018, p. 281-282; Heilman \& Parks-Stamm 2007, p. 49-50. 
eeuwenlang degenen zijn geweest die werkten om het gezin te onderhouden. ${ }^{74}$ Grote ondernemingen zijn van oudsher ingericht door en voor mannen, waardoor het werkklimaat veelal gericht is op mannen. ${ }^{75}$ De eerdergenoemde kenmerken van een stereotiepe man suggereren dat leiders die beschikken over mannelijke kenmerken betere leiders zijn dan wanneer zij beschikken over meer vrouwelijke kenmerken. ${ }^{76}$ Leidinggevende kwaliteiten zijn zelfverzekerdheid, assertiviteit en competitiviteit. Dit zijn kenmerken die meer stroken met het mannelijk stereotype, waardoor vrouwen het risico lopen om als minder capabel voor leidinggevende functies te worden gezien. ${ }^{77}$

Daarbij komt dat de heersende gedachte is dat van vrouwen wordt verwacht dat zij meer mannelijke eigenschappen aannemen, willen zij kunnen doorgroeien naar hogere functies en het überhaupt kunnen volhouden in leidinggevende functies. ${ }^{78}$ Het beschikken over mannelijkheid wordt dus nogal eens als noodzakelijke kwaliteit beschouwd om een managementfunctie te bekleden. ${ }^{79}$ Een nadelig gevolg is dat vrouwen die zich deze mannelijke kenmerken aanmeten en leiderschapsrollen vervullen al snel worden gezien als onaardig en niet-sociaal, omdat deze kenmerken niet overeenkomen met de stereotiepe kenmerken van vrouwen. ${ }^{80}$ Het mannelijke leiderschapsstereotype kan aldus beïnvloeden hoe vrouwen zich gedragen en ontwikkelen, waardoor het stereotype in stand wordt gehouden. ${ }^{81}$ Het voornaamste probleem is dat zolang mannen het overwicht houden in topfuncties, mannelijk leiderschap veelal zal prevaleren bij vrouwen en mannen. ${ }^{82}$

\subsection{Similar attraction paradigm (soort zoekt soort)}

Naast de problematiek rondom genderstereotypering is er nog een sociologische oorzaak waardoor vrouwen mogelijk minder snel de top weten te bereiken dan mannen, namelijk het similar attraction paradigm. Deze theorie houdt in dat mensen besluiten van anderen het meest positief beoordelen als zij die anderen als (min of meer) hetzelfde beschouwen. ${ }^{83}$ Mensen met dezelfde achtergrond vinden elkaar eerder aardig en beoordelen elkaar gunstiger. ${ }^{84}$ Het is een onbewuste manier van mensen om onzekerheid te minimaliseren en daarmee het vertrou-

75 C. Villiers, Achieving gender balance in the boardroom: Is it time for legislative action in the UK?, Legal Studies 2010, afl. 4, p. 541.

76 Ellemers 2018, p. 277; Heilman \& Parks-Stamm 2007, p. 50.

77 Heilman \& Parks-Stamm 2007, p. 50; Rudman \& Phelan 2015, p. 28.

78 M.C.L. van den Brink e.a., Black box tussen aanbod, werving en selectie van vrouwen, Radboud Universiteit Nijmegen 2016, p. 13 en 18-19.

79 Connell 2002, p. 101.

80 Heilman \& Parks-Stamm 2007, p. 59-60; Rudman \& Phelan 2015, p. 29-31.

81 Villiers 2010, p. 541.

82 Villiers 2010, p. 541.

83 R.L. Leonard Jr., Cognitive complexity and the similarity-attraction paradigm, Journal of Research in Personality (10) 1976, afl. 1, p. 83-88.

84 
wen in een goede voortgang te maximaliseren. ${ }^{85}$ Het old boys-netwerk is daar een voorbeeld van. Uit onderzoek blijkt dat zelfs als expliciet wordt gezocht naar een vrouw, de vertrouwelijkheid die een old boy wekt bij de zittende $\mathrm{RvB}$ en $\mathrm{RvC}$ het veelal toch wint van de vrouwelijke kandidaat. ${ }^{86}$ Kroeze stelt eveneens dat de zittende functionarissen zich niet bewust zijn van de neiging om risico's uit te sluiten door gelijkenissen te zoeken. ${ }^{87}$

Tegenstanders van vrouwenquota geven aan dat vrouwen benoemd moeten worden op grond van persoonlijke kwaliteiten en niet vanwege het feit dat zij vrouw zijn. Met dit argument realiseren zij zich niet dat de invulling van de persoonlijke kwaliteiten subjectief is en juist wordt ingekleurd door de gelijkenissen tussen hen en de sollicitant. ${ }^{88}$ Het fenomeen 'excuustruzen' wordt door de zittende functionarissen gecreëerd omdat juist het criterium 'kwaliteit' aan stereotypering onderhevig is. Hiermee wordt de kwaliteit van vrouwen evenwel stelselmatig ondergewaardeerd en zullen zij vaker expliciet moeten bewijzen dat zij geschikt zijn voor een rol, terwijl mannen dat niet hoeven te doen. ${ }^{89} \mathrm{Nu}$ het mannelijke stereotype doorwerkt in bijna alle facetten van het leven, kan het ook doorwerken in de wijze waarop vacatures worden beschreven en hoe kandidaten gezocht en benaderd worden. ${ }^{90}$ Hierdoor zullen vrouwen sneller ongeschikt worden geacht voor de functie en zullen zij zich bovendien niet altijd herkennen in de functie. ${ }^{91}$ Het probleem lijkt derhalve in het onderbewuste van de mens te liggen. In de topfuncties die openstaan, worden nog steeds voornamelijk mannen benoemd, zoals ook blijkt uit recente cijfers. Indien een benoemingscommissie uitsluitend bestaat uit mannen, wordt het lastig om de onbewuste voorkeur van 'soort zoekt soort' te doorbreken. Een vrouw in de commissie kan deze onbewuste stereotyperende gedachten doorbreken.

\section{Enkele conclusies}

De wettelijke regeling die geldt voor grote nv's en bv's bepaalt dat ten minste $30 \%$ van hun $\mathrm{RvB}$ en $\mathrm{RvC}$ dient te bestaan uit vrouwen, respectievelijk mannen, voor zover de zetels worden verdeeld over natuurlijke personen. Dit percentage is een streefcijfer. Uit recente onderzoeken over de jaren 2016, 2017 en 2018 blijkt dat het aantal vrouwen dat is benoemd in de $\mathrm{RvB}$ of $\mathrm{RvC}$ aan het toenemen is, maar ook dat de groei traag verloopt. ${ }^{92}$ In dit artikel hebben wij onderzocht of er een relatie bestaat tussen de samenstelling van selectie- en benoemingscommissies en het percentage vrouwen in de top. Gebleken is dat de selectie- en benoemings-

85 Powell 2012, p. 122.

86 Van den Brink e.a. 2016, p. 17-18.

87 Kroeze 2013.

88 Kroeze 2013.

89 Van den Brink e.a. 2016, p. 13.

90 Van den Brink e.a. 2016, p. 30-35.

91 Villiers 2010, p. 539.

92 Zie de resultaten van de Bedrijvenmonitor Topvrouwen 2017, p. 26, de Dutch Female Board Index 2018, p. 4, en de Emancipatiemonitor 2018, p. 9. Zie voorts ook Perquin-Deelen 2018. 
commissies overwegend uit mannen bestaan. Er zijn weinig benoemingscommissies waarin vrouwen de meerderheid vormen. Er zijn zelfs meer commissies waarin geen vrouwen zitting hebben dan commissies waarin de meerderheid uit vrouwen bestaat. Daarnaast zijn wij ingegaan op sociologische factoren - genderstereotypering en het similar attraction paradigm, oftewel 'soort zoekt soort' waaruit afgeleid kan worden dat de samenstelling van de selectie- en benoemingscommissies gevolgen heeft voor de keuze van kandidaten en daarmee voor de samenstelling van de $\mathrm{RvB}$ en $\mathrm{RvC}$. Om genderstereotypering en het similar attraction paradigm tegen te gaan is het van belang dat het aantal vrouwen in selectieen benoemingscommissies toeneemt. Wij bevelen daarom aan dat in de Nederlandse Corporate Governance Code wordt opgenomen dat elke selectie- en benoemingscommissie minimaal één vrouwelijk, respectievelijk mannelijk, commissielid kent. Een bijkomend voordeel hiervan is dat, nu deze commissie door de RvC uit zijn midden wordt ingesteld, ${ }^{93}$ RvC's die geen vrouwelijke commissarissen kennen, hierdoor extra gestimuleerd zullen worden om in elk geval één vrouwelijke commissaris te benoemen.

93 Als deze commissie niet is ingesteld, zal deze taak bij de RvC berusten. Dan geldt dezelfde aanbeveling. 